with a scope wider than anything previously conceived, is being put into operation. Not only is existing erosion to be checked, but the system of farming is to be reorganized to protect the land against further damage and to procure the best return from it; grazing will be fenced into paddocks, water-supplies for drinking and irrigation will be preserved and developed, and afforestation will be carried out on a larger scale. Limitation of stock-an idea which conflicts with traditional customs-seems to be the crux of the whole matter: Africans have still to be persuaded that one first-class beast is worth ten scrubs. Experiments at Thaba Nchu and elsewhere have demonstrated that in a relatively short period the carrying capacity of the veld can be almost doubled by limitation of stock and proper control of grazing. The Government appeals for voluntary restriction by the people themselves, but if this fails will take whatever steps may be necessary to save the land while there is still time. For the landless Africans who depend entirely upon wage-earning for their livelihood, a village settlement is to be erected on a Trust farm adjoining Kingwilliamstown; and if this experiment succeeds similar villages will be built elsewhere. These will differ materially from the old 'locations'. 'The land will be laid out in plots of about one-quarter acre and on each one a house to cost about $£_{1} 100$ will be built by Government. Occupants will be selected, will pay a moderate rent, and have the option of purchasing house and plot either for cash or in instalments spread over twenty years.

The Review of the Activities of the Department of Native Affairs for the year 1944-s from which we have culled these facts covers a wide field and affords an impressive summary of what the Union Government is doing for the seven million Africans for whose well-being it is responsible. Until 3 I March last their education was financed by proceeds of the polltax plus a block grant of $£ 340,000$ from the general exchequer. The Union Parliament has now approved of the whole cost of native education (amounting to $2 \frac{1}{2}$ million pounds a year) being provided from national funds; and the four-fifths of the native tax hitherto ear-marked for the education of Africans will revert to general revenue. Last year the Union Parliament made upwards of 353,000 Africans eligible for Old Age Pensions, and also made statutory provision for pensions under certain conditions to blind Africans who have attained the age of nineteen: there are 27,000 blind Africans on the register. Another II 7,000 Africans are to benefit from an invalidity scheme by which every African sixteen years old or over, who is totally and permanently incapable of working, will receive an allowance equal to that given to Old Age pensioners. The Review describes the training given to the students in agricultural institutions; tells of the School that is being erected for the training of female Home Welfare officers; and sets out a scheme for training Veterinary Assistants. The action that the Government has taken to promote the training of Africans as physicians seems not to fall within the purview of the Native Department; but we may note here that bursaries of the value of $\chi^{22} 5$ a year are being provided for African students at the Witwatersrand university, and a hostel is being built for them at a cost of $£_{33,000}$.

\title{
International Contacts
}

\section{Recent Activities of the Institute}

WrTh the cessation of hostilities in Europe the Institute has been able to renew its contacts with many former members in France and Belgium. We are happy to be in correspondence again with several members of the Executive Council, including Professor P. Rivet, Père Dubois and Professor N. de Cleene. We have also received publications from the Société des Africanistes, and the Société d'Ethnologie de Paris.

In addition to the governments of British territories in Africa and of the Union of South Africa, most of which have resumed or increased their annual donations, the Governments of French West Africa, French Equatorial Africa, the French Cameroons and Madagascar, as well as the Belgian Colonial Ministry, have signified their interest in the work of the 
Institute by generously contributing to its funds. The Comte de Briey, who has served as a member of the Institute's Consultative Committee, was able, during a recent visit to Belgium, to give an account of the Institute's war-time activities and future plans to the Belgian Colonial Minister and the Directors of the Institut Royal Colonial Belge and the Université Coloniale de Belgique.

Opportunities for the closer participation of Africanists in the U.S.A. are being actively explored. Dr. Edwin Smith provided the Institute with a valuable review of the possibilities on his return from the United States, in the light of which American members have been invited to give us their views. A number of constructive suggestions and offers of assistance have been received from them in response to this inquiry.

\section{Handbook of African Languages}

The grant from the British Colonial Office towards the work on the Handbook of African Languages has been renewed for a second year; Miss Bryan's article in this number of Africa will give some indication of the problems to be faced in this undertaking. A bibliographical and lexicographical study of recent works on Bantu languages, by Professor Doke of Witwatersrand University, is now in the press, and further publications in connexion with the Handbook are in preparation.

\section{Research in the British Cameroons}

A FIRST report has been received from Dr. Kaberry outlining her plans for the conduct of her study on the position of women in the British Cameroons (Bamenda division) (see Africa, January 1945). For the present she is basing her work on Kimbaw, investigating social conditions there and in the surrounding villages.

\section{Ethnographic Survey of Africa}

Tre Institute has undertaken the preparation of an Ethnographical survey of Africa. The importance, for scientific research and for social development and welfare, of a comprehensive survey of the ethnic groupings, distributions and salient social conditions of the peoples of Africa has been urged in the Institute itself and elsewhere for a number of years. Recently the need for an organization which would assemble, collate and make available the wealth of existing but uncoordinated material has been more acutely realized in connexion with plans for economic and general social development after the war. In the absence of such a survey much of the extant material is virtually inaccessible to scholars and governments alike. In addition to published work there is, in the governmental archives and the records of private institutions, much valuable material which for lack of organization rather than from any desire to restrict access has hitherto remained unavailable.

The Survey will, it is hoped, be of direct value to all Africanists and will also help to ensure that the limited funds and personnel available for further research are directed where they are most needed and most likely to produce results of scientific and practical value. Its object is to present a systematic outline of existing knowledge with a critical bibliography of available sources and so to provide reliable data of value to students and those professionally concerned with African affairs.

The Institute has received a grant for a five-year period from the British Colonial Development and Welfare Fund towards the cost of the Survey and has welcomed assurances of readiness to co-operate from both French and Belgian official and scientific organizations. In West Africa the work will be carried out in close collaboration with the I.F.A.N. which is undertaking a 'Répertoire des Populations' in French West Africa. While it is necessary to envisage an inquiry extending over some considerable time, and to frame plans accordingly, provisional results will be made available as the Survey progresses. 